\title{
The Housewife and the Soldier \\ Tamil constructions of womanhood in the age of migration
}

Af Øivind Fuglerud

Hvordan har medgiftens betydning andret sig $i$ takt med diasporiseringen af det tamilske samfund? Med fokus på tamilske konstruktioner af kvindelighed, bliver de historiske og kulturelle kontekster medtenkt $i$ debatten om arrangerede agteskaber.

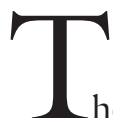

he present article outlines a refracted discourse on the position of women found among Tamils from Sri Lanka. Since the early 1980s Sri Lanka has been in a state of civil war fought between the Sinhalese army and the forces of the Liberation Tigers of Tamil Eelam (LTTE), who fight for a separate state called Eelam. While exact numbers are not available, unofficial sources indicate that as much as 700.000 Tamils have fled Sri Lanka as a result of the encompassing violence (Special Report, Hinduism Today, April 1997). This exodus, unfolding during a period when Western immigration regulations became increasingly strict, has led Tamils all over the world in search of security and economic opportunities, some of them to the Nordic countries. ${ }^{1}$

While Tamil gender constructions is an interesting issue under any circumstance, the recent public debate on arranged marriages among immigrants provides it with a particular relevance. In Norway, as in Den- 
mark, propositions have been brought forward in the name of "human rights", which break fundamentally with longstanding traditions in migrants' countries of origin e.g. the suggestion to limit the possibility of marrying relatives. While I do not wish to draw any hasty conclusions on the good or evil of such traditions, the question of their role in new social circumstances deserves a more thorough discussion than what is normally accorded in tabloid newspapers and televised discussions. My main aim in this article is to establish a basis for discussing arranged marriages among the people in question by providing background information on the "rooting" of this phenomenon in Sri Lankan institutions and conceptions. This way of framing the question follows from my general understanding that Western discourses on women's rights so far have had little impact on Tamil self-perceptions - female or male. Rather, new perspectives on gender among Tamils inside and outside Sri Lanka are connected to the ways in which war and migration transform home-country ideals and practices from within.

Any debate on gender within the Sri Lanka-Tamil society will have to include a discussion of dowry. This social practice of the wife and the wife's side bringing property into the new family is the formal expression of the establishment of a hierarchical alliance between the two families involved. Also, dowry provides women a central symbolic position in the fabric of Tamil society and culture. On April 182001 we find in the comment section of Tamil Guardian, a London newspaper serving the English-speaking diaspora, a thorough and original discussion of the dowry phenomenon in the modern world. The article is worth quoting at length. After pointing out that the upheavals caused by war in Sri Lanka have radically changed the situation of many Tamil families, the female author argues:
"In these days of redefining sexual roles, the dowry too can be reinterpreted to find a place within this Tamil culture. One possibility is to view it as a means of allowing a woman to acquire a husband who is of a quality and standard to satisfy her budget and need. A wealthy woman can afford to select a husband with educational and material considerations suitable to her needs. A poor woman will have to settle for a less well-educated or less wealthy man .... There is nothing wrong with such a system.”

While admitting that the system is not perfect and that women often have been too cowed to realise that they should get "their money's worth", the author argues:

"It [the dowry system] must be viewed as a system of women acquiring, and men selling, the attributes of a husband. And as the capitalistic world has taught us, the quality of anything depends on the price paid for it .... A woman should have the freedom to decide whether to pay the going rate for her husband, just as a man wishing to sell himself on the open market should have the freedom to do so ... The market should know what the going rate is for a doctor, lawyer or candlestick maker. An open market is essential if the system is to be secure for all parties" (Tamil Guardian April 18 2001).

This text touches on at least three aspects of the situation of Tamil women. Firstly, it obviously reflects an effort of re-orientation, a need to accommodate to a modern world where traditions no longer "go without saying because they come without saying" as Bourdieu once put it. Secondly, the text informs us that dowry is here understood not as landed property but as money, as a means to obtain required services. This is a recent and very important change in the conception of dowry that I will return to below. Thirdly, the confident tone in the article tells us that the author is prepared to make claims on the part of her 
Tamil sisters. While I do believe that her promotion of capitalist logic is rather unusual, the female confidence itself has a basis in the Sri Lanka-Tamil social formation. This is a point of general importance. Too much work on gender has taken the position of women in the Western world as the only point of reference (Walker 1995). Today, in line with general perspectives on modernity, gender identities are often no longer seen as defined by society but as achieved through inter-personal negotiations (Moore 1999). In what is now known as queer studies the focus has shifted from "being" to "doing" - the issue is no longer social discourse but the way you enact your sexuality (Graham 1998).

The present article wishes to question this understanding. I agree with Moore (1999) that available anthropological data suggest that most people do not find their gender identities particularly fluid or open to choice. This applies as much to those people who are seemingly resisting gender norms as it does to those who are apparently accepting them. This is not to deny that transformed discourses on gender are integral parts of the processes of rapid social change. However, the effects of such changes do not, on the level of the individual, necessarily manifest themselves as freedom from categorical boundaries. Partly such freedom may be restricted by the availability of symbolic elements from which to construct alternative discourses in which behaviour can be grounded - partly the openness and insecurity of modern society may encourage the individual to embrace tradition.

This point seems particularly important in multicultural and diasporic settings, where gender concerns not only sexual division of labour and social statuses of women and men broadly understood, but where gendered valuations and symbolic principles often gain increasing importance as internal and external boundary markers. "Diaspora", as the term is used today (Clifford 1994, Brah 1996), denotes a conditi- on put into play through the experience of being from one place and of another. It is identified with the idea of particular sentiments towards a real or imagined distant homeland, whilst being formed by a place of settlement where one is constructed in and through difference. This is what Anthias (1998) points to as the "problem of intersectionality": the need to investigate the differentiated uses to which ethnicity and cultural syncretism is put by men and women and by different class categories in settings characterised by transnational migration. That women are central in the reproduction of ethnic and nationalist ideologies and as transmitters of cultural rules has often been observed (Anthias and Yuval Davis 1989). However, in terms of both economic structures, social practice, and symbolic principles, the study of gender in transnational settings needs to take into account both internal relationships and the insertion of particular sections - economic and other - of transnational communities into host societies. In the Tamil case we find different constructions of gender, which in complex ways are linked to class positions in the Tamil society.

\section{The TAmil Social Formation}

The most important explanation for the relative success of Tamils in securing emigration and protection as refugees in Western countries has been the previous existence of family members outside Sri Lanka. In the post-independence period Tamils started migrating to find work when Sinhala politicians in the 1950s consciously sought ways of reducing Tamil entry into the country's public sector. When the war started these early emigrants became instrumental in assisting relatives in need of a safe haven. To Tamils, going abroad to settle often involves the use of professional "agents". The only people with access to the amount of money demanded by such agents were those with relatives already in the West. 
That kinship ties are important to the process of migration would probably qualify as a truism. Since the 1960s analysts have been interested in the importance of social networks for processes of chain migration and the role of family and friends in settling new immigrants in receiving countries (Boyd 1989). The important point in the present context is that Tamil kinship and the practice of arranged marriages have attained a spatial form, which today structures a perception of their own community in transnational terms. We must look at this in greater detail.

Most Tamil migrants in the Nordic countries originate in Jaffna, the northernmost administrative district of Sri Lanka. While Pfaffenberger $(1982,28)$ has claimed that Tamil Sri Lanka is an extremely conservative region which "to this day preserves ... the very heart of the South Indian cultural design", there are also differences between the island and the mainland. In particular, some of the more overt forms of oppression affecting Hindu women in India did not penetrate into Jaffna. One reason for this is probably the fact that Brahmins, the priestly caste, never attained a position of power. The politically most important group in the Sri Lanka-Tamil social landscape of the last few hundred years has been the Vellalar caste who owned not only most of the land but the temples, and who treated serving priests as salaried officials. The Vellalars constitute what in other regions has been called a "dominant caste" (Raheja 1988).

In consequence of this situation; the Sri Lanka-Tamil society has been relatively free from extreme religiousness (Thiruchandran 1998). This undoubtedly has affected the situation of women beneficially. For example, in pre-colonial society the formal type of marriage used to be simple, the central ritual being the tying of the tali - the gold chain - around the bride's neck by the bridegroom and the gift of sari cloth to the bride (Tambiah, H.W. n.d.). The absence of the elaborate Vedic rites, where the polluting and subordinate status of the female sex is a theme, indicates a relative equality between the two genders. This is the situation we find encoded in the book called Tesawalamai - literally "the customs of the land" - a compilation of rules from Jaffna pertaining to inheritance, property rights, dowry and divorce. Tesawalamai was codified by the Dutch governors in the early part of the $18^{\text {th }}$ century, approved by local chieftains, and later adopted as law by the British. It is generally accepted that these rules contain elements that protect the rights of women (Tambiah, S.J. 1973). The rules on property divide property into three categories: the property a man inherits from his parents, the property of the woman given by her parents at the time of her marriage ("dowry"), and the property acquired by the man and wife during their lifetime. Dowry belongs to the wife, a man's inheritance to the husband, and the acquired property to the husband and wife together. A particularly interesting aspect of Tesamalamai is the rules provided in case of divorce and remarriage. For example, if a wife wants to divorce her husband it is implied that she should get her dowry back and half of the acquired property (Thiruchandran 1998, 132). This was at a time when women were not gainfully employed. In other words, her entitlement to half the acquired property is for the services rendered as a housewife and mother. This right must have reduced women's dependence on others significantly.

What has been said does not mean that Tamil Sri Lanka to this day has been a paradise for women - far from it. Women's property rights in Sri Lanka have in recent times been located within a cultural universe characterised by male bias. Like in India, the conception has been that a wife should treat her husband like a god. Proverbs emphasise the inquisitive, jealous and quarrelsome nature of women. To what extent this male bias came with the kinship and 


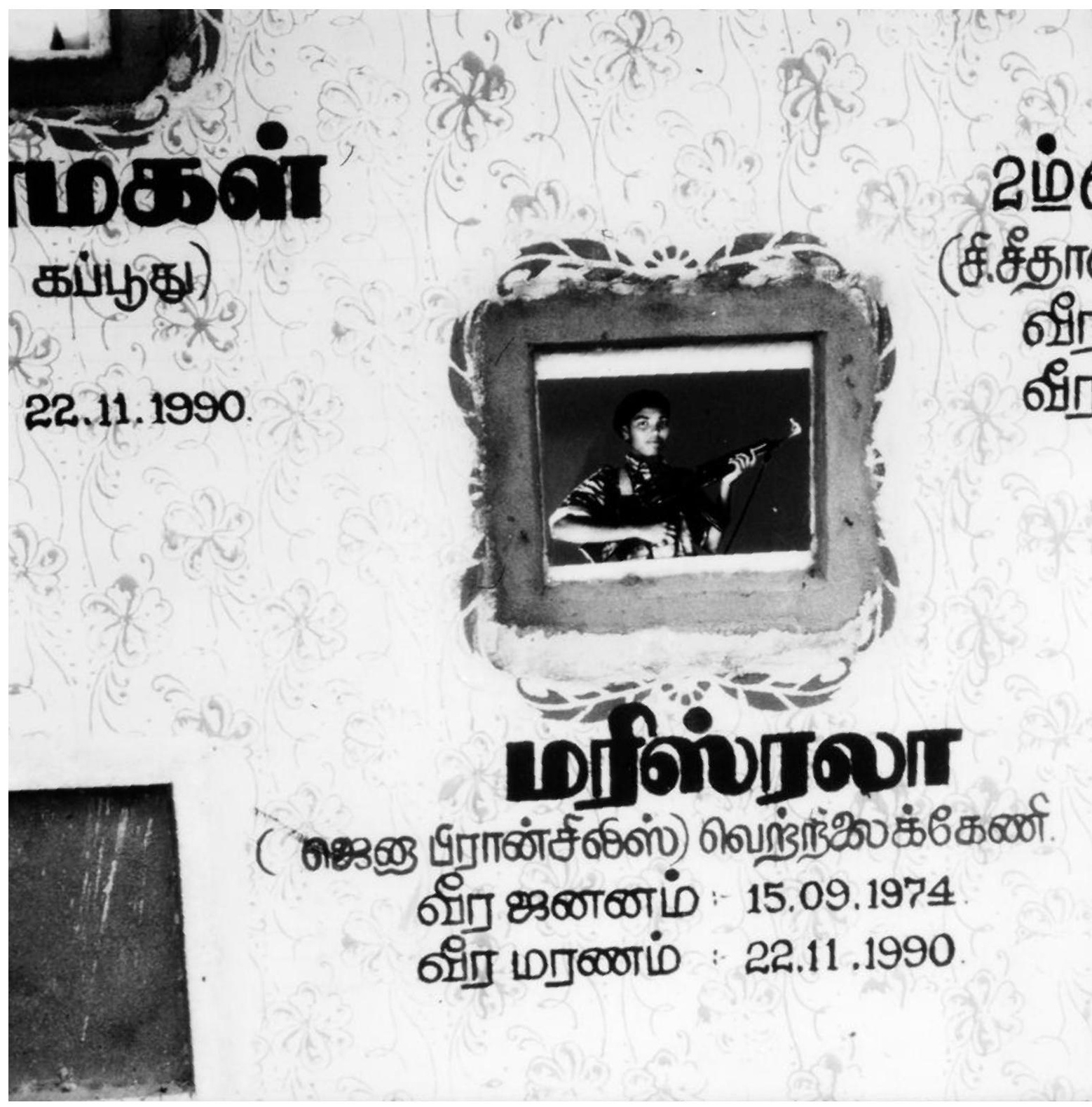

Murals celebrating female LTTE martyrs, Jaffna 1995. Foto: Oivind Fuglerud 


\section{(U) ல1:சும) பயூத்த்த்குற். उ ஆனனம் 18.03 .1970 . ராண்ம் :- 23.11 .1990$.}

property system or is part of a later "brahmanisation" of Jaffna society is an interesting question for historical research. What we can say at this point is that in recent times there have been internal contradictions between property rights and cultural conceptions in the social construction of gender.

In different ways throughout history these contradictions have been aggravated by the phenomenon of migration. The historical importance of migration in the Tamil areas stems from it being one of the few, and therefor one of the major, vehicles of capitalisation in the area (Fuglerud 1999). With the British development of the Malay States and the Straits settlements (Singapore, Penang and Malacca) in the latter half of the nineteenth century, possibilities for salaried work were opened (Ramasamy 1988). The export of manpower under the British Empire injected large amounts of capital into the economic system of Jaffna. This altered the logic of the dowry system. The possibility in the Tesawalamai to provide dowries from "acquired property" was in this new situation seized upon to cross sub-caste or even caste boundaries by marrying daughters to men of higher status. Individually negotiated marriages created a basis for the culturally specific caste-class formation to be found in Jaffna. Through family connections established and reproduced through marriage a consolidated economic middle class was created within the upper-middle range of the traditional caste structure (Banks 1957). At the same time the possibility of gaining social mobility through marriage raised the level of dowries needed to attract a groom suited to the new level of expectation.

The pre-capitalist ideal, and at least to some extent practice, in Jaffna society was marriage between what anthropologist call "cross-cousins"; that is children of brother and sister (David 1973, Trautman 1981). This provided a degree of social security for 
women. With the use of dowries to raise the position of families in the caste hierarchy through marriage, a woman's position becomes more precarious. Not only is she in such instances married out of her own family but is married to a man from a family of higher social position. As long as Jaffna society remained localised, however, this precariousness was mitigated by the nature of the dowries. Even with the remittances from migration during British rule, agricultural land and a house normally remained the core of a woman's dowry (Banks 1957). One consequence of this was that more often than not the married couple would settle among relatives of the wife. Since the established practice was for parents to move out of their own house and leave it to the marrying daughter, and since brothers normally remained unmarried until husbands had been found for their sisters, the marrying woman would still have her family around her. With Tamil society turning transnational this has changed. Dowries today go into finding bridegrooms with secure positions in countries of settlement, while the presence or absence of supporting networks for the wife is of secondary importance. To make matters worse, dowries are mainly given in cash now. This drastically alters the role and function of dowry. Instead of one dowry helping to finance another, floating as landed capital within the system of family networks, the cost of transport and settlement papers now siphons off this capital to greedy agents. To women themselves, the consequences of this changing pattern are predominantly negative. Not only do marriages outside the family, and in particular to men settled abroad, reduce the possibility of support from relatives in daily chores and in situations of difficulty. The inflation of dowries stemming from migration and the need to spend it on agents and transport, create a situation where many women are not able to marry at all. According to a survey conducted by the northern district administration, in Jaffna women in 1994 outnumbered men six to one (Associated Press April 29 1994). There is reason to believe that the difficulties of establishing a meaningful family life helps to explain the large number of women recruited into the armed liberation movement. In the Tamil areas of Sri Lanka there is today a very clear conception that those who can afford to go have already left, and that the ranks of the LTTE are mainly filled with youngsters who have no other options. Undoubtedly, there is a class dimension to the two positions of the soldier and the migrant.

\section{The Housewife ANd THe Soldier}

Against the backdrop of what has been said two points can be made. One is general, that social change and modernisation tend to unfold in culturally specific ways. The other is particular, that the upheaval resulting from war and migration seems to have further broken apart the internally refracted construction of gender outlined above. If we return to the comment section of Tamil Guardian, we find here an illustration of these two points. Time and again the position of women in society is here brought up for discussion. The framework of this discussion is very rarely individual freedom in the western sense. Rather the situation of Tamil women in the diaspora as grounded in tradition is posed against the female liberation fighter remaining in Eelam. Passionate inputs like the following are quite common:

"(T)he liberation struggle has forced the Tamil community in Sri Lanka to face the prejudices and practices that were ingrained in their society and to reassess them. Men and women fight side by side for a cause that they firmly believe in. The women of Eelam have surpassed not only their Tamil counterparts in the West, but have also leapfrogged many Western women in terms of the duties they regularly perform and the respect and 
recognition they receive" (Tamil Guardian April 24 1999, 14).

On the other hand there is the worry that life in the west may corrupt the specific character of Tamil society. In protecting this character, traditions - good or bad constitute a bulwark:

"Our whole culture is based on tradition. It is what makes us Tamil. Why do you think it is that we go to the temple although we cannot understand all that is being said? Why do we not meat on Fridays? Why do we eat with our right hands? Tradition. Tradition. Tradition .... We should cherish our originality. The dowry system is part of that originality. Dowries do not ruin marriages, I argue that they provide a foundation for marriage" ( Tamil Guardian October 9 1999, 6)

The Liberation Tigers of Tamil Eelam (LTTE), who undoubtedly constitutes the most important social and political force in today's Sri Lanka-Tamil society, is one of the few liberation movements to use female soldiers actively in all capacities including combat and suicide missions. Since the early 1980s they have had a Women's Front in their organisation. The clearest voice representing the LTTE on women's issues has been Adele Ann, later Adele Balasingham, the Australian wife of LTTE's "chief ideologue" Anton Balasingham, who lived and worked with the LTTE in Sri Lanka during the 1990s. In one of her works we find a very clear condemnation of the dowry practise:

"In the past two decades in particular, the dowry system has emerged as an acute social problem .... It has polluted and corrupted the social sanctity of marriage. It has reduced the human relationship between woman and man into a calculated financial contract. The practice of dowry has plunged a vast number of families onto the brink of poverty and despair. Most importantly, this practice has de- prived inestimable numbers of women of their right to marriage and family life" (Ann 1994, 30).

Interestingly, the same author in a more recent book (Balasingham 2001, 301-303) has explained how she later prevented the leadership of the LTTE from enacting a law putting a stop to the tradition. She was afraid that the issue, considering the controversy surrounding it, could turn out to be "the opening of a Pandora's box in the Tamil community". Also, researching the topic further, she came to the conclusion that "the practise of dowry in its modern form (is) more indicative of the social oppression of women than an issue at the centre of their oppression". The end of the matter was that the Justice Department of the LTTE, on the instructions of its leader, did not ban dowry practices but removed the husband's control over his wife's property after marriage.

Whether one looks upon the material implications of dowry practices as a cause or a symptom of female oppression, there is little doubt that these practices have been intertwined with cultural constructions of femininity. Of particular importance in this respect is the concept of karpu or chastity, which has been a metaphor for the understanding not only of personal conduct and family affairs, but of caste-related, ethnic and national purity (Pandian 1982). Каrpu is in every way a key concept in Tamil culture, often exemplified by Sita from the epic Ramayana, who patiently endures her husband's suspicions of infidelity despite the fact that she lives only for him. Chastity, or marital fidelity, is not an abstract ethical value but a substantial and dynamic reality concerning a woman's inner nature (Shulman 1991). Karpu, in the deepest sense, concerns women's flesh and blood. It has a moral substantiality continually flowing in and between people through an almost unlimited number of culturally defined taboos and practices, reflecting the 
non-separability of norms, actions, and substance in the Hindu universe (Marriott 1976). While the chaste wife brings prosperity and happiness to her social surroundings, any fault or normative transgression affects not only the acting person but the people with whom one shares bodily substance, primarily one's family, and in the case of married women one's husband.

Against this concept of karpu the LTTE posits the value of heroism (viram). For example, in a statement issued 8 March 1992, the International Women's day, the leader of the LTTE stated:

"Women can succeed on the ideal path towards their own liberation only through joining forces with a liberation movement.

(Women) can change into revolutionary women who have heroism (viram) abandonment of life (tiyakam), courage and self-confidence. Only when women join forces with our revolutionary movement that has formulated a path to liberation of our women, shall our struggle reach perfection".

In addition to the International Women's Day, the LTTE celebrates its own Women's Day on 10 October, the day of the death of the first female LTTE martyr, Malathi, who in 1987 swallowed cyanide not to be taken capture during battle.

The happily married and properly dowered woman living up to traditions and the young female in LTTE's battle fatigues constitute alternative images of womanhood in Tamil society. This is reflected in several poems written by young women themselves taking part in the armed struggle, for example one entitled "She, the Woman of Tamileelam!" by Captain Vanathi, who died in 1991 at the age of 27 in the battle over Elephant Pass:

Her forehead shall be adorned not with kunkumam ${ }^{2}$ but with red blood

What is seen in her eyes is not the sweetness of youth but the firm declarations of those who have fallen

Her neck will carry no thali

but a cyanide capsule

She has embraced not men

but weapons!

Here kunkumam, the red powder used to put the pottu on the forehead, and the tali, both signs of married women, are counterpoised to insignia of military battle.

The same dichotomy is brought out in a discussion between Radhika Coomeraswa$\mathrm{my}^{3}$, the leader of International Center for Ethnic Studies in Colombo and UN Rapporteur on the oppression of women, and Adele Balasingham (2001). The induction of women into the fighting force, Coomeraswamy argues, has resulted in a major transformation with regard to the "symbolic representation of women in Tamil society". As the negative mirror image of the "auspicious married woman with many children and material wealth" represented by the "wearing of rich saris, brilliant jewellery, silver toe-ring and a red pottu on her forehead" she portrays the Tiger women with short hair and "without make-up, jewellery or ostentation". This image, she argues, is devoid of any of the traditional Tamil characteristics of the feminine. In terms of the politics involved, her point is that the female soldiers of the LTTE are "cogs in the wheel of someone else's designs and plans", "implementers of policy made by someone else, by men". Adele Balasingham's answer $(2001,289)$ is that women joining the LTTE have identified Sinhala racism as the basic structure of oppression to which they are subjected. Participating in a struggle to free themselves from this mode of oppression "is a process of empowerment in itself". It was the objective conditions of genocide and the urgency to resist and defend against the forces of destruction, that Tamil men and women entered the process of armed struggle.

The theoretical dimension of this dis- 
cussion is outside the scope of this article. However, Balasingham makes a point of importance to the present discussion, in the sense that very few women left in Sri Lanka can today have any realistic hope of living up to the traditional image in terms of "rich saris and brilliant jewellery". This is an ideal that can be, and indeed $i$, pursued only by emigrants or with the help of remittances from emigrants.

\section{Separate Ways to the Future?}

The natural conclusion to draw from what has been said may seem to be that gender constructions in Eelam and in the diaspora are developing in different directions. That while men and women fight side by side at home, arranged marriages outside the family and the new role of dowries entail increased inequality and insecurity for women abroad. Undoubtedly this is part of the story. It is not the whole story, however. While the question of who leaves and who stays is in every way connected to economic positions, there are in terms of symbolic structure elements that mediate between the two constructions of womanhood. On the one hand female sexual purity remains a subtext in the LTTE's conceptualisation of the Tamil motherland (tayakam) and the women of this motherland. On the other hand, the image of the armed female soldier is undoubtedly a source of inspiration for many women in the diaspora. Young Tamil women in Norway often see these soldiers as expressing the spirit of Kannaki, the heroine of the Hindu epic Cilappatikaram, who after having been made widow by the king tears one of her breasts off in rage and destroys the city of Madurai. While her strength to destroy does stem from her karpu, like her armed sisters in the LTTE, Kannaki uses this strength actively to rectify wrongs that have been done to her. To women in Norway, the female soldiers, interpreted through Kannaki's story, represent a model through which to overcome the pas- sivity of their current role while retaining the bond to a historically grounded construction of femininity.

This symbolic interconnection may serve as an illustration of the two main arguments I have tried to make in this article. The first, a general one, is that there are other possible standards for modernisation than the assumedly "liberated" Western individual. The second argument, more specific, is that Tamil culture - presumably like most others - contains its own symbolic resources through which the position of individuals can be negotiated and redefined in situations of social change. In debates on the situation of immigrant women in Western countries there is a need to take this into account.

\section{Noter}

1. The article is mainly based on the author's general knowledge of Tamil culture and Tamil migrants stemming from several fieldworks in Sri Lanka and Norway during the last 15 years.

2. Kunkumam is red powder used to put on the pottu, the spot carried on the forehead. Like the tali the pottu is a sign of married women, here counterposed to military insignia.

3. "LTTE Women - Is This Liberation?", The Sunday Times January 5th 1997.

\section{REFERENCES}

- Ann, A. (1994): Unbroken Chains: Explorations into the Jaffna Dowry System. Malathi Press, Jaffna. - Anthias, F. (1998): "Evaluating 'Diaspora': Beyond Ethnicity?", in Sociology, Vol. 32, No. 3: 557580 .

- Anthias, F. and Yuval-Davis, N. (1989): Racialised Boundaries: Race, Nation, Gender, Class and the Anti-racist Struggle. Routledge, London. - Balasingham, A. (2001): The Will to Freedom: An Inside View of Tamil Resistance. Fairmax Publishing, Mitcham.

- Banks, M. Y. (1957): The Social Organization of the Jaffna Tamils of North Ceylon, with special reference to Kinship, Marriage, and Inheritance. Cambridge University: unpublished Ph.D dissertation. 
- Boyd, M. (1989): "Family and Personal Networks in International Migration: Recent Developments and New Agendas", in International Migration Review Vol. 23, Fall.

- Brah, A. (1996): Cartographies of the Diaspora.

Routledge, London.

. Clifford, J. (1994): "Diasporas", in Cultural Anthropology 9: 302-38.

. David, K. (1973): "Until Marriage Do Us Part: A Cultural Account of Jaffna Tamil Categories for Kinsmen", in Man 8: 521 - 35 .

- Fuglerud, Ø. (1999): Life on the Outside: The

Tamil Diaspora and Long Distance Nationalism.

Pluto Press.

. Graham, M. (1998): "Follow the Yellow Brick Road: An Anthropological Outing in Queer Space", in Ethnos 63 (1): 102-32.

- Marriott, M. (1976): "Diversity without dualism", in B. Kapferer (ed.): Transaction and Meaning: Directions in the Anthropology of Exchange and Symbolic Behaviour. Institute for the Study of Human Issues, Philadelphia.

- Moore, H.L. (1999): "Gender and Other Crises in Anthropology", in H.L.Moore (ed.): Anthropological Theory Today. Polity Press, Cambridge. - Pandian, J. (1982): “The Goddess Kannagi: A Dominant Symbol of South Indian Tamil Society", in J.J. Preston (ed.): Mother Worship. University of North Carolina Press, Chapell Hill.

- Pfaffenberger, B. (1982): Caste in Tamil Culture: The Religious Foundations of Sudra Domination in Tamil Sri Lanka. Maxwell School of Citizenship and Public Affairs, Syracuse, N.Y.

- Raheja, G.G. (1988): The Poison in the Gift: Ritual, Prestation, and the Dominant Caste in a North Indian Village. University of Chicago Press, Chicago and London.

- Ramasamy, S. (1988): Sojourners to Citizens: Sri Lankan Tamils in Malaysia 1885 - 1965. Sri Veera Trading, Kuala Lumpur.

- Shulman, D.D. (1991): "Fire and Flood: The Testing of Sita in Kampan's Iramavataram", in P.
Richman (ed.): Many Ramayanas: The Diversity of a Narrative Tradition in South Asia. University of California Press, Berkeley.

- Tambiah, H.W. (not dated): The Laws and

Customs of the Tamils of Jaffna. Revised Edition. Women's Education and Research Centre, Colombo.

. Tambiah, S.J. (1973): "Dowry, Bridewealth and the Property Rights of Women in South Asia", in Jack Goody and S.J. Tambiah: Bridewealth and Dowry. Cambridge University Press, Cambridge - Thiruchandran, Selv (1998): The Spectrum of Femininity: A Process of Deconstruction. Vikas Publishing, New Delhi.

- Trautman, T. (1981): Dravidian Kinship. Vistar Publications, New Delhi.

- Walker, L. (1995): "More than Just Skin Deep: Fem $(\mathrm{m})$ ininity and the Subversion of Identity", in Gender, Place and Culture 2 (1): 71-6.

\section{SUMMARY}

The article argues that Sri Lankan Tamil construction of womanhood is contradictory. While the traditional property system provides women with specific legal rights and a degree of social security, this system is located within a male biased conception of culture. Processes of migration have in different ways aggravated this contradiction throughout history. In particular, dowries have provided a channel for converting remittances from migration into enhanced social status. The article argues that this development is not beneficial to women in general.

Øivind Fuglerud, dr.polit, forskningsleder, Norsk Institutt for forskning om oppvekst, velferd og aldring (NOVA) 